\title{
À procura d'água: cata-ventos americanos nos jardins de Fortaleza'
}

Searching for Water: American Windmills in the Gardens of Fortaleza

\author{
ALINE DE FIGUEIRÔA SILVA² \\ Universidade Federal da Bahia / Salvador, BA, Brasil
}

RESUMO: Este artigo reflete sobre a relação entre os atributos do meio natural e o cultivo de jardins públicos entre o final do século XIX e o início do XX na cidade de Fortaleza, localizada na região Nordeste do Brasil. Trata, primeiramente, das espécies vegetais arbóreas utilizadas e da criação de lagos nos jardins públicos, relacionados aos aspectos hídricos e à abundância de sol na cidade. A seguir, aborda a presença de cata-ventos ou moinhos eólicos americanos, documentando sua procedência e utilidade para o bombeamento d'água subterrânea, armazenada em reservatórios de ferro, bem como a relevância desse sistema para a irrigação dos jardins e seu desmonte. $\bigcirc$ artigo privilegia fontes documentais escritas e iconográficas, a exemplo de jornais, álbuns, revistas, fotografias, cartões-postais, bem como registros de cronistas e memorialistas e literatura especializada sobre cata-ventos americanos, ampliando o quadro de referências para a historiografia do paisagismo no Brasil no que diz respeito à presença de artefatos utilitários na manutenção dos jardins públicos.

PALAVRAS-CHAVE: Cata-ventos. Jardins. Fortaleza. Relações Brasil-Estados Unidos. Séculos XIX e XX.

ABSTRACT: This article analyzes the relationship between environmental specificities and the cultivation of public gardens in the late nineteenth and early twentieth century in the city of Fortale$z a$, in the northeast region of Brazil. First, it examines the planted tree species and the creation of ponds in public gardens relative to hydric aspects and sun abundance in the city. Second, the essay describes the introduction of American windmills, known as cata-ventos in Brazil, by documenting their origin, their utility for pumping underground water stored in iron tanks, the use

\begin{abstract}
1. Este artigo resulta da tese de doutorado em Arquitetura e Urbanismo intitulada Entre a implantação e a aclimatação: o cultivo de jardins públicos no Brasil nos séculos XIX e XX, apresentada à Faculdade de Arquitetura e Urbanismo da Universidade de São Paulo (FAUUSP) e financiada pela Fundação de Amparo à Pesquisa do Estado de São Paulo (Fapesp) e pela Dumbarton Oaks Research Library and Collection/Harvard University, Estados Unidos.

2. Arquiteta e urbanista pela UFPE, Mestre em Desenvolvimento Urbano pela UFPE e Doutora em Arquitetura e Urbanismo pela USP. Professora Adjunta da Faculdade de Arquitetura da UFBA. E-mail: $<$ aline.figueiroa@ufba.br>.
\end{abstract}


3. Nesse conjunto, ressaltamos os trabalhos de Rosa Grena Kliass (1993); Hugo Segawa (1996); Aparecida Vaz da Silva Bahls (1998); Liana de Barros Mesquita (1998); Silvio Soares Macedo (1999); Vladimir Bartalini (1999); Luís Fernando da Luz (1999); Carlos Gonçalves Terra (2000); Rubens Andrade (2003); Maria Regina Matos Paradeda (2003); Cândida Freitas (2006); Luiz Fernando Dutra Folly (2007); Siomara Barbosa Stroppa de Lima (2009); Paulo José Lisboa Nobre, Marizo Vitor Pereira e Isaías da Silva Ribeiro (2009); Ana Rita Sá Carneiro e Ramona Pérez Bertruy (2009); Ana Rita Sá Carneiro (2010); Aline de Figueirôa Silva (2010); Guilherme Mazza Dourado (2011); Bia Hetzel e Silvia Negreiros (2011); Cristiane Maria Magalhães (2012); Carlos Gonçalves Terra (2013); Anna Karine de Queiroz Costa Bellini (2014). of this system for garden irrigation, as well as their disappearance. The paper uses iconographic and written documentary sources, such as newspapers, albums, magazines, photos, postcards, as well as chronicler's reports and memoirs, and specialized literature on American windmills. Thus, it offers new references for garden historiography in Brazil concerning the existence of utilitarian artifacts for maintaining public gardens.

KEYWORDS: Windmills. Gardens. City of Fortaleza. Relations between Brazil and the United States of America. 19th and 20 th centuries.

Oestudo dos jardins brasileiros e o interesse pela sua preservação vêm, paulatinamente, se expandindo desde o final dos anos 1990, em que se ressaltam as pesquisas, publicações e ações de intervenção em jardins públicos. Nesse sentido, avança no Brasil a produção acadêmica no campo da história do paisagismo em relação ao acervo remanescente do século XIX e início do XX. ${ }^{3}$

Se, por um lado, vimos assistindo a um alargamento dos recortes geográficos estudados, por outro, observamos, na produção historiográfica do país, a ênfase no estudo da difusão das matrizes paisagísticas europeias, notadamente oriundas da Paris haussmanniana, bem como o protagonismo dos engenheiros e paisagistas franceses que atuaram no Brasil, em sua maioria na região Sudeste.

Desse modo, carecemos de reflexões aprofundadas quanto ao papel dos aspectos fisiográficos e climáticos como mediadores da implantação dos jardins públicos no Brasil a partir das últimas décadas do século XIX, seus modos de usufruto e suas próprias condições de sobrevivência. Esses aspectos são minimizados diante das abordagens que privilegiam as filiações formais entre os jardins brasileiros e europeus em um século marcado pela exploração botânica, circulação profissional, progresso científico e importação de artefatos industrializados.

Considerando esse panorama, buscamos refletir sobre a relação entre os atributos do meio local e o cultivo de jardins públicos no Brasil - passeios, praças ajardinadas e parques - entre o final do século XIX e as três primeiras décadas do 
XX, particularmente na cidade de Fortaleza, capital do estado do Ceará, localizada na região Nordeste do país. ${ }^{4}$

Abordamos, inicialmente, a relação entre os critérios de seleção de espécies vegetais arbóreas e a criação de lagos, de um lado, e os aspectos hídricos e a incidência solar, de outro. A seguir, tratamos da presença de cataventos ou moinhos eólicos de tecnologia americana ${ }^{5}$ nos jardins de Fortaleza. ${ }^{6}$ Documentamos sua procedência, utilidade para o bombeamento d'água subterrânea, armazenada em reservatórios de ferro, a relevância desse sistema e seu desmonte. Celebrizada por seus "verdes mares" alencarinos, , a cidade foi dotada de numerosos cata-ventos, utilizados para provisão d'água doce, fosse para o consumo doméstico, fosse para a irrigação dos jardins públicos, incorporando-se à sua fisionomia.

\section{O MEIO E OS JARDINS DE FORTALEZA}

O cultivo e a conservação dos jardins, na condição de artefatos simultaneamente naturais e culturais, estão submetidos às forças da natureza e à manipulação humana, que os modela utilizando elementos vivos e inertes. A vegetação, em seus diferentes estratos, é um elemento fundamental na composição dos jardins - juntamente com coretos, pavilhões, fontes, lagos, bancos e esculturas, além do traçado que os articula -, bem como no seu usufruto por parte da população.

Em Fortaleza, a alta incidência de sol foi um fator importante na seleção e nos modos de plantio da vegetação arbórea, em razão da necessidade de sombra como condição favorável à permanência nos jardins públicos. A vegetação constituía um recurso de amenidade climática e remodelação da fisionomia da cidade, trazendo benefícios diretos ao bem-estar da população, à estética e à salubridade urbana.

Desse modo, a seleção das espécies botânicas, especialmente das árvores, nativas ou exóticas, que identificamos nos jardins, podia vincular-se tanto aos seus aspectos ornamentais (floração, atributos das copas, troncos e folhagens) quanto utilitários (sombreamento, rápido crescimento e resistência à estiagem).

Revistas e jornais dos anos 1920 e 1930 ressaltavam a arborização das vias e jardins da cidade, ora enaltecendo as ações realizadas pelo poder público, ora reclamando contra sua escassez, prescrevendo seus benefícios ou ainda apelando à população para conservá-la.
4. A latitude de Fortaleza é 0343'02" Sul, portanto há menor variação de temperaturas na cidade ao longo do ano, dada sua proximidade à linha do Equador. O primeiro semestre do ano corresponde ao período mais chuvoso na cidade, ao passo que o segundo semestre é mais seco.

5. Ao longo do texto, utilizamos os termos americano, norte-americano e estadunidense como adjetivos gentílicos relativos aos Estados Unidos da América, a exemplo do que pratica o autor do livro Arquitetando a "Boa Vizinhança": arquitetura, cidade e cultura nas relações Brasil-Estados Unidos, 1876-1945. Cf. Fernando Atique (2010, p. 30).

6. Na pesquisa da qual resulta este artigo, identificamos cata-ventos com morfologia semelhante aos de Fortaleza cuja procedência acreditamos ser americana em cartões postais que retratam a Praça Sinimbu (Praça Euclides Malta), em Maceió, e a Praça da República (antigo Largo da Campina, depois Largo da Pólvora e Praça D. Pedro II, hoje dividida em três partes denominadas de Praça João Coelho, Praça da República e Praça da Sereia), em Belém. Ainda observamos outro exemplar na Praça da Matriz de Iguatu, município do interior do Ceará, em foto constante no álbum Terra Cearense, de 1925 . Um cata-vento americano fabricado pela Aermotor Company existiu no Parque das Águas de Cambuquira, no sul de Minas Gerais, também ilustrado em cartões postais. Contudo, seu expressivo aparecimento deu-se na cidade de Fortaleza, que tomamos como objeto deste artigo, em específico.

7. O epíteto Cidade dos Verdes Mares pelo qual For- 
taleza é conhecida alude ao romance Iracema (1865), do escritor José de Alencar (1829-1877).

8. Cf. Ceará Illustrado, n. 28, janeiro de 1925, [s.p.]. É importante lembrar que, naquele ano, a cidade de Fortaleza contava com pelo menos seis jardins públicos: o Passeio Público, o Parque da Liberdade, o Jardim 7 de Setembro da Praça do Ferreira, o Jardim Nogueira Accioly da Praça Marquês do Herval, o Jardim Pedro Borges (ou Caio Prado) da Praça da Sé e a Praça General Tibúrcio, não se dispondo, contudo, de informações sobre seu estado de conservação.

9. Cf. Ceará Illustrado, n. 28, janeiro de 1925, [s.p.].

10. Registramos nosso agradecimento ao colega biólogo Joelmir Marques da Silva, Mestre e Doutor em Desenvolvimento Urbano pela Universidade Federal de Pernambuco (UFPE) e Mestre em Diseño, Planificación y Conservación de Paisajes y Jardines pela Universidad Autónoma Metropolitana, México (UAM). O profissional colaborou com nossa pesquisa de doutorado realizando a identificação da vegetação dos jardins a partir da análise da morfologia dos espécimes vista na documentação iconográfica, cotejada com fontes documentais e bibliográficas e algumas informações coletadas in loco atualmente. Sobre essa metodologia, ver Aline de Figueirôa Silva e Joelmir Marques da Silva (2016, p. 83-99).

11. O arquiteto José Liberal de Castro (Fortaleza, 1926) é autor de diversos trabalhos sobre a história da arquitetura cearense e a história urbana da capital,
Exemplo disso é uma matéria publicada no Ceará Illustrado de janeiro de 1925 que enfatizava a necessidade "duma praça intensamente arborisada, onde nas horas de canicula a população pudesse abrigar-se á sombra das arvores", recomendando o plantio de "mangueira ou outras plantas fructiferas e exóticas" no Parque da Liberdade. ${ }^{8}$ A mesma matéria abordava as vantagens do plantio de árvores, bem como apresentava justificativa para a escolha de algumas espécies. Apontava a chegada da estação chuvosa como oportuna para avançar no serviço de arborização da cidade, a fim de facilitar "a péga das arvores", que deveriam ser "de especies resistentes ás seccas", citando o oitizeiro (Licania tomentosa), o fícus-benjamim ou a figueira (Ficus benjamina) e a canafístula (Peltophorum dubium). 9

De fato, entre as espécies arbóreas, o exótico fícus-benjamim encontrava-se em vários jardins de Fortaleza - espécie de rápido crescimento e copa densa, atributos importantes para garantir a necessária provisão de sombra (Figura 1).10

Documentamos ainda a existência dos nativos oitizeiros (Licania tomentosa) no Passeio Público e no Parque da Liberdade, castanholas (Terminalia catappa) e mongubeiras (Pachira aquatica) ${ }^{11}$ Estas últimas, também nativas, já estavam presentes em alguns logradouros da cidade, mesmo antes de serem ajardinados, e eram muito referidas nas crônicas e memórias de escritores locais. ${ }^{12}$ Trata-se de espécies umbrosas, portanto, apropriadas ao clima quente. A nativa canafístula (Peltophorum dubium), por sua vez, estava presente na Praça Visconde de Pelotas, ajardinada em 1933.13

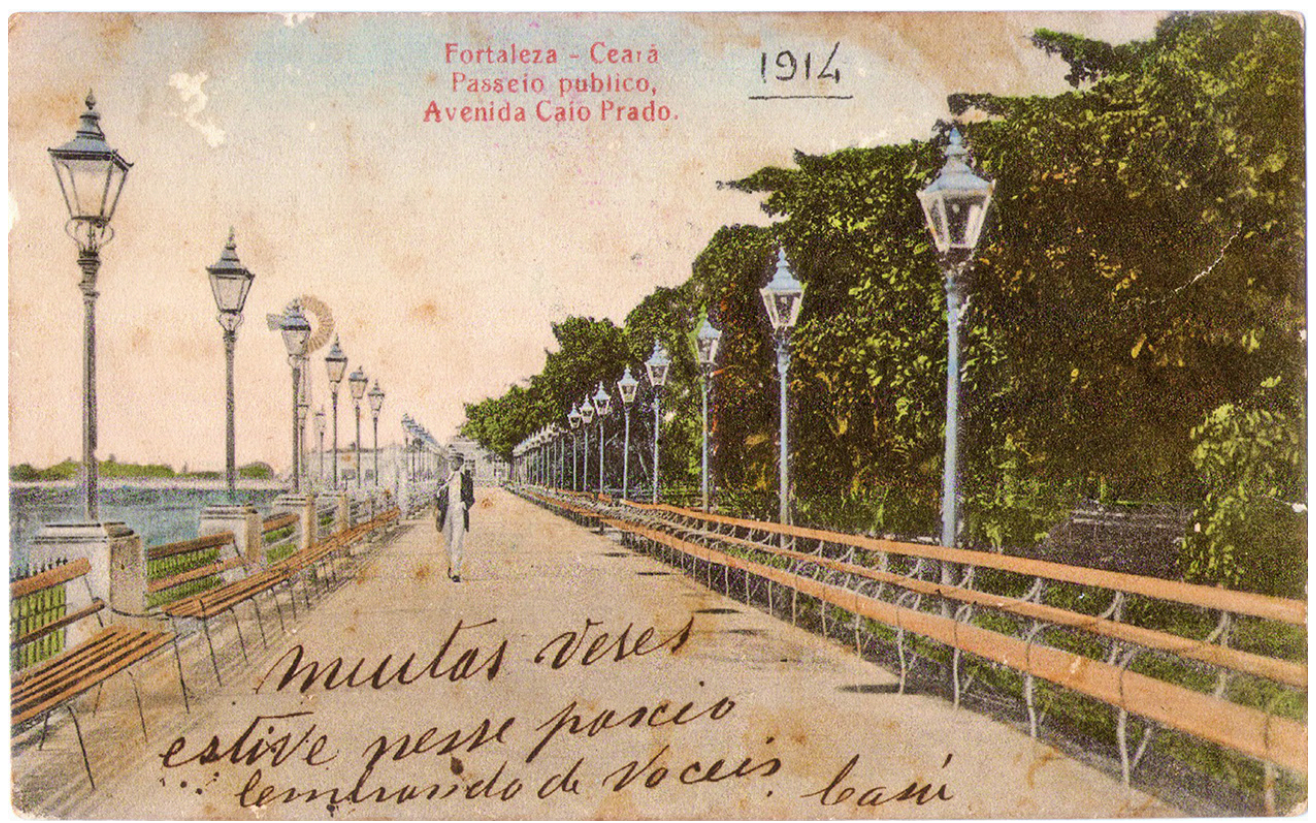

Figura 1 - Passeio Público de Fortaleza (primeiro plano); à direita, renque de fícus; à esquerda, o cata-vento. Cartão postal. Coleção Hugo Segawa, São Paulo. 
Famoso na crônica histórica fortalezense era o oitizeiro existente junto à Igreja de Nossa Senhora do Rosário, na Praça General Tibúrcio, pois, conforme conta o cronista Otacílio de Azevedo (1892-1978), "sob sua fronde, procuravam refrescante abrigo contra os ardores da canícula" aqueles que ali paravam para conversar sobre arte, política, religião ou a vida alheia. ${ }^{14}$

A presença da vegetação nos logradouros da cidade também foi registrada no Correio do Ceará por um viajante oriundo do Recife em passagem pela capital cearense em 1930, ao ressaltar "suas praças ajardinadas com esmerado gosto" e "a arborização vasta e elegante, que muito concorre para a amenidade do seu clima". ${ }^{15}$ Uma nota que circulou no mesmo jornal durante o mês de julho daquele ano dirigia às mães de família "o instante appello de, todos os dias, pela manhã, mandarem deitar um jarro d'agua ao pé das tenras arvores e inclinar os seus filhinhos a serem amigos das plantas". ${ }^{16} \bigcirc$ excesso de sol e a necessidade d'água eram, enfim, desafios postos à implantação e à conservação dos jardins.

Observamos também nos jardins públicos de Fortaleza a exiguidade de elementos aquáticos contemplativos, talvez em razão da evaporação causada pela predominância de dias quentes ao longo do ano, ou por deficiências nos serviços regulares e infraestruturas de abastecimento d'água e/ou por seu custo de manutenção.

A região foi afetada por períodos de estiagem, a exemplo das secas de 1877-1879, 1888, 1900, 1915 e 1919, ensejando medidas como a perfuração de poços de uso público e a criação de obras emergenciais a fim de empregar retirantes sertanejos, provendo-os de trabalho e alimento. ${ }^{17}$ A grande estiagem de 1877-1879 impôs dificuldades à operação da Ceará Water Work Company Limited, concessionária que realizava o serviço de fornecimento d'água em Fortaleza, mas que já se encontrava em crise. ${ }^{18}$

Nesse sentido, localizamos relatos que indicam o aproveitamento de recursos naturais para a criação de um lago decorativo no terceiro plano do Passeio Público e de um lago navegável no Parque da Liberdade, em detrimento de fontes e lagos que precisariam ser alimentados artificialmente.

$\bigcirc$ Passeio Público foi inaugurado por fases a partir de 1880 e, durante muito tempo, constituiu o principal logradouro público ajardinado de Fortaleza. Era estruturado em três planos, correspondentes a três níveis topográficos, entre a cidade e a praia. Porém, segundo o engenheiro e cronista João Nogueira (1867-1947), o negociante Antônio Tito Rocha, que já o explorava para a prática de patinação por volta de 1879, efetuou melhoramentos no "terceiro além de sua atividade projetual e docente junto à Universidade Federal do Ceará (UFC). Num bilhete de sua autoria, redigido em 1973 por ocasião da encomenda ao Escritório Burle Marx \& Cia. de um projeto paisagístico para o Teatro José de Alencar, em Fortaleza, indica espécies utilizadas na antiga arborização da cidade, conforme publicado no livro Roberto Burle Marx e o Theatro José de Alencar: um projeto em dois tempos. No manuscrito, afirma Liberal de Castro: "a arborização antiga era de mongubeiras e castanholas (amendoeiras). Aparecem também os cafés". Cf. Ricardo Figueiredo Bezerra e Fernanda Rocha et al. (2012, p. 35).

12. Menções às mongubeiras nos logradouros da cidade constam em Raimundo de Menezes (2006 [1938], p. 47); João Nogueira (1942, p. 151); João Nogueira (1954 [1933], p. 12); Otacílio de Azevedo (2012 [1980], p. 55; 133); Raimundo Girão (1979, p. 129).

13. Ver João Nogueira (1942, p. 149).

14. Cf. Otacílio de Azevedo (2012 [1980], p. 129).

15. Nota originalmente publicada em 6/8/1930 sob o título "Fortaleza" no Jornal Pequeno, editado na capital pernambucana. Cf. Correio do Ceará (16/8/1930, p. 7).

16. Cf. Correio do Ceará (31/7/1930, p. 7).

17. Ver Gustavo Barroso (1962, p. 283; 370); Raimundo Girão (1979, p. 225; 1983, p. 33); José Liberal de Castro (1987, p. 212; 230; 234; 245) e Sebastião Rogério Ponte (1999, p. 28).

18. Ver Raimundo Girão (1983, p. 29) e Sebastião Rogério Ponte (1999, p. 82). 
19. Cf. João Nogueira (1954 [1933], p. 14).

20. Cf. Gustavo Barroso (1962, p. 233).

21. Ver Fortaleza 1910 (1980).

22. Cf. Otacílio de Azevedo (2012 [1980], p. 95). plano, que foi ajardinado, construiu um lago, que era alimentado pelas águas do riacho Pajeú". ${ }^{19}$

P Parque da Liberdade, por sua vez, começou a ser estruturado em 1890 e foi remodelado e rebatizado de Parque da Independência em 1922. A primeira intervenção consistiu no aproveitamento da Lagoa do Garrote, que "se viu aprisionada em margelas de cimento, para se tornar o lago central de belo jardim público", ${ }^{20}$ descrição correspondente às fotos publicadas no álbum Fortaleza 1910. ${ }^{21} \mathrm{~A}$ lagoa delimitava uma "minúscula ilha", 22 na qual, já no século XX, foi erguido um pavilhão conhecido como Templo do Cupido. O parque tornou-se um dos espaços de recreação da população, e a antiga lagoa, um de seus atrativos, recanto de contemplação e local para o passeio de barcos (Figura 2).

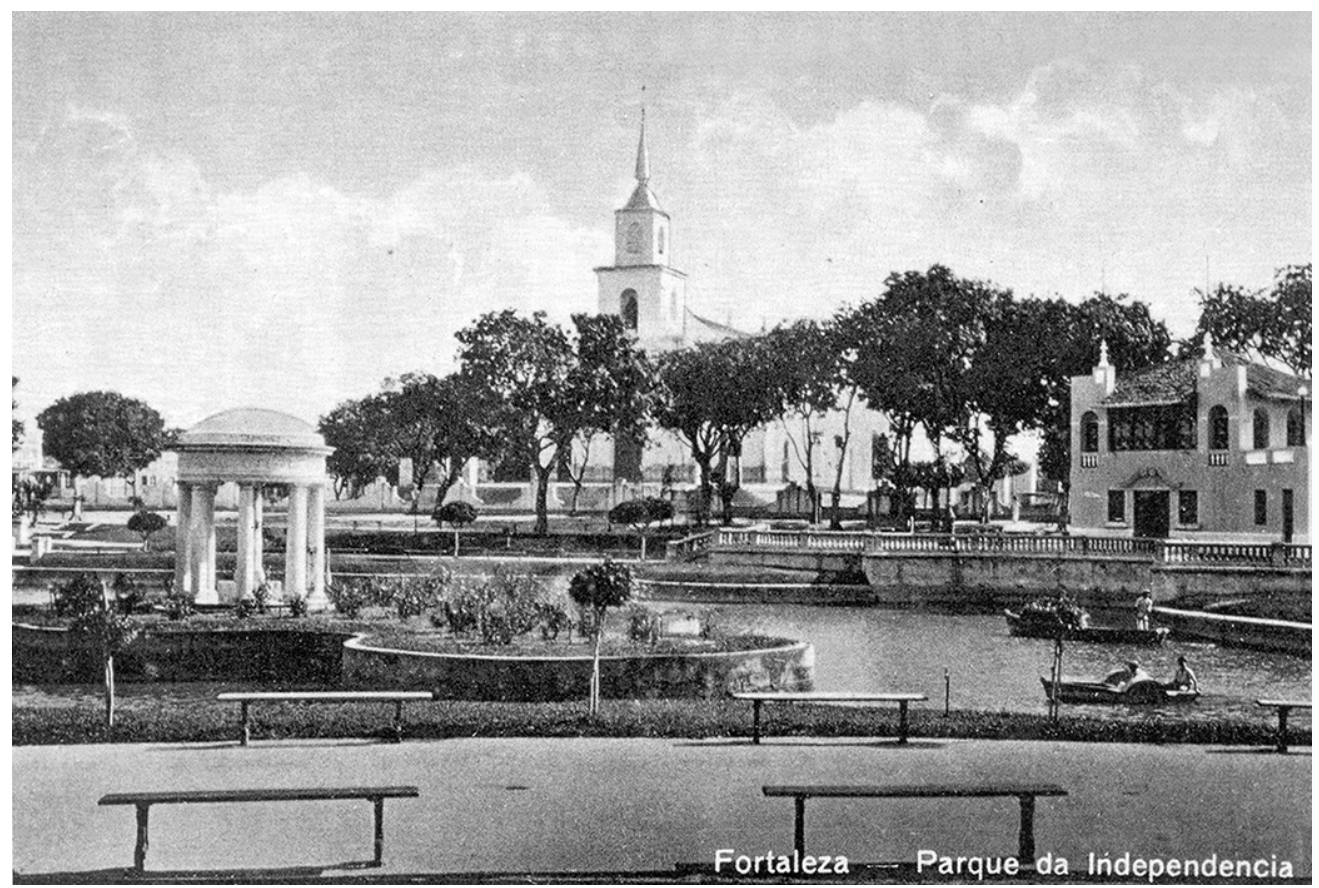

Figura 2 - Parque da Independência lantes e atual Parque da Liberdade, também conhecido como Cidade da Criança), o Templo do Cupido e o passeio de barcos no lago; ao fundo, a Igreja do Sagrado Coração de Jesus, Fortaleza, c. 1930. Acervo Museu da Imagem e do Som do Ceará, Fortaleza.

O Jardim 7 de Setembro, criado na Praça do Ferreira em 1902, dispunha de um conjunto de bacias como parte do seu sistema de irrigação, demonstrando, portanto, sua função utilitária (Figura 3). 
Posteriormente, na década de 1930, algumas praças foram dotadas de peças aquáticas na ocasião de seu ajardinamento. Em 1930, foi instalada uma fonte luminosa no Jardim Tomás Pompeu da Praça Comendador Teodorico ou da Lagoinha. A peça foi importada da Alemanha e inaugurada naquele ano, quando a cidade já possuía redes de energia elétrica, ${ }^{23}$ coexistindo com o sistema a gás, e de abastecimento d'água, embora este último serviço atendesse apenas parcialmente a população quando de sua inauguração, em 1926. ${ }^{24}$

Finalmente, a Praça Visconde de Pelotas, onde haviam sido erguidas duas grandes caixas-d'água como parte do novo serviço de abastecimento, foi ajardinada em 1933 e dotada de um lago central (Figura 9), de modo que afirmamos a interdependência entre as características do meio e os recursos infraestruturais necessários à implantação e manutenção dos jardins.

Antes que o referido sistema de fornecimento d'água, inaugurado em meados dos anos 1920, pudesse ser disponibilizado para a irrigação de jardins e a alimentação de lagos e fontes, o uso dos cata-ventos foi uma solução significativa no tocante à rega e à manutenção de tais espaços, conforme veremos a seguir.

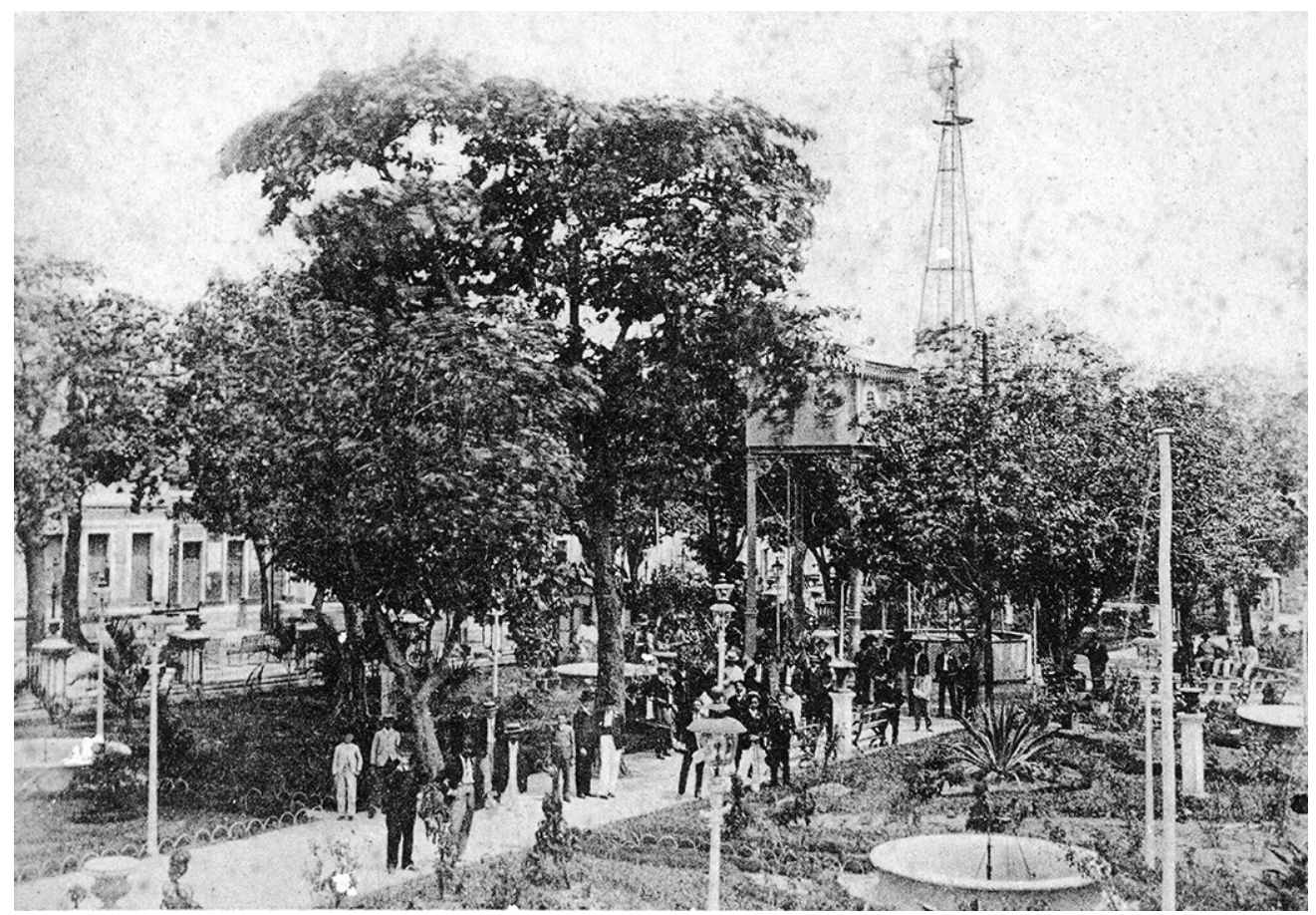

Figura 3 - Jardim 7 de Setembro da Praça do Ferreira (atual Praça do Ferreira), a cacimba, o cata-vento e a caixa-d'água, bacias para irrigação, Fortaleza. Coleção Nirez, Fortaleza.
23. No caso do sistema elétrico, para o funcionamento da fonte, foi necessário, contudo, fazer uma instalação especial por um engenheiro inglês. Ver Banco do Nordeste do Brasil (1984, p. 15).

24. Ver Sebastião Rogério Ponte (1999, p. 82) e Emy Falcão Maia Neto (2015, p. 133). 
25. Ao longo do texto empregamos frequentemente a palavra cata-vento, tal como circulava em fontes de época adiante referidas, bem como foi apropriada por autores cearenses, sendo ainda de uso corrente no Brasil. Utilizamos também a expressão moinho (eólico ou de vento), conforme tradução do inglês windmill e registrada contemporaneamente. Ver Antônio Houaiss (2009, [s.p.]).

26. Registramos nosso agradecimento ao colecionador Miguel Ângelo de Azevedo (Nirez), filho do escritor Otacílio de Azevedo, pela consulta ao seu acervo particular, arquivo iconográfico inescapável para o olhar científico e afetivo sobre o passado fortalezense, bem como pela cessão de imagens para a referida pesquisa de doutorado.

27. Cf. Otacílio de Azevedo (2012 [1980], p. 39).

28. Cf. ibidem, p. 40.

29. Cf. ibidem, p. 72.

\section{CATA-VENTOS PARA A IRRIGAÇÃO DOS JARDINS}

\section{À procura d'água doce: os cata-ventos nas memórias e no espaço da cidade}

Em Fortaleza, deu-se o notável aparecimento de cata-ventos ou moinhos de vento ${ }^{25}$ nos quintais das residências e espaços públicos da cidade, os quais utilizavam a energia eólica como força motriz para puxar água de poços e cacimbas.

Embora tais equipamentos estejam fartamente ilustrados na iconografia fortalezense (Figuras 1, 3, 4, 5, 7), ${ }^{26}$ há poucas informações bibliográficas extensas sobre sua origem, aquisição, funcionamento e contexto de onde foram importados.

Testemunha ocular de sua presença na Praça do Ferreira, Otacílio de Azevedo recorda que, quando chegou à cidade, por volta de 1910, ali, "à falta de óleo, gemia um velho catavento, sobre uma cacimba gradeada. Enchia uma imensa caixa-d'água pintada de roxo- terra" ${ }^{27}$ Deparava-se com "um belíssimo jardim - rosas, dálias, papoulas - enfim uma imensa variedade das mais belas flores". ${ }^{28}$ Noutra crônica sobre a Praça do Ferreira, o autor informa a existência de "uma caixa d'água e um catavento, que puxava água para aguar os jardins". ${ }^{29}$

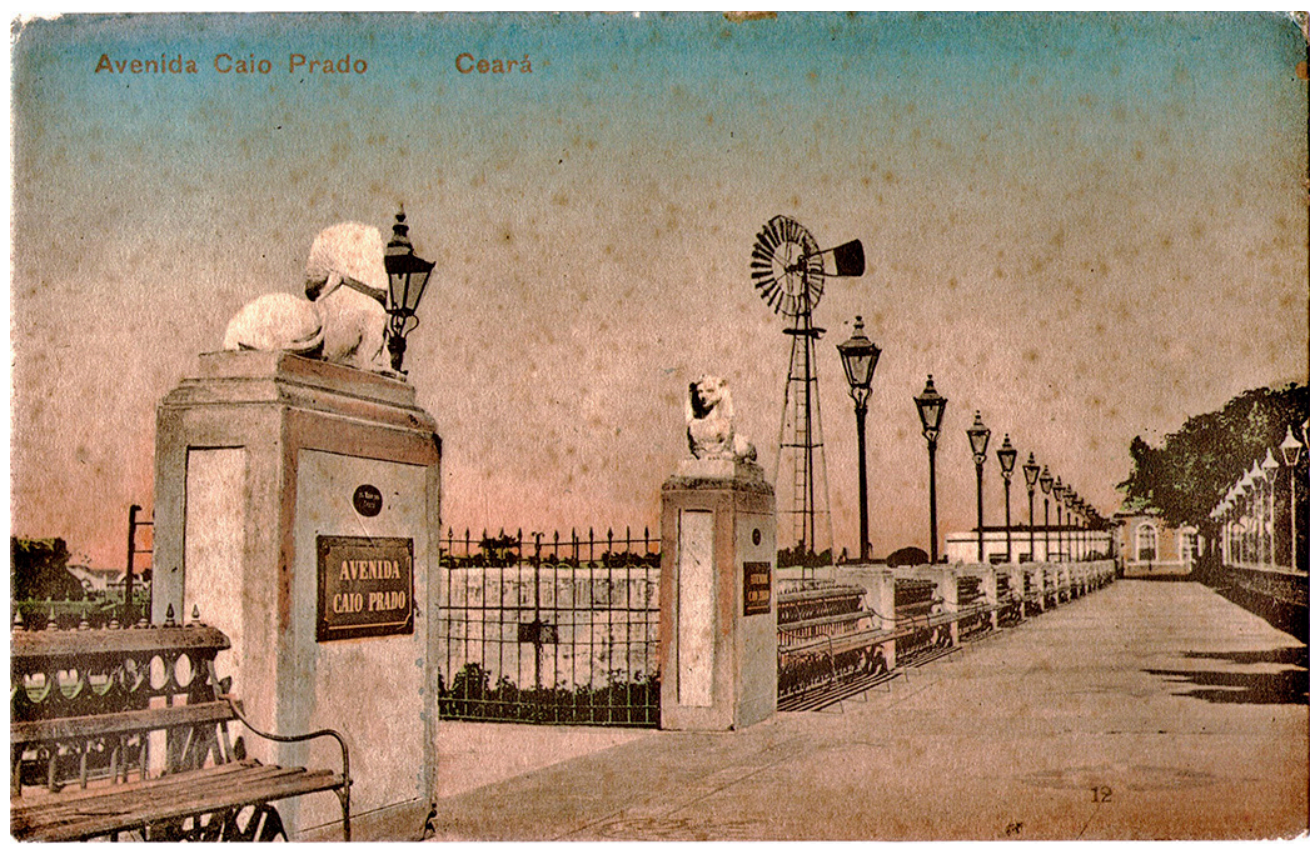

Figura 4 - Passeio Público (primeiro plano); ao fundo, o cata-vento, Fortaleza. Cartão Postal. Coleção Hugo Segawa, São Paulo. 
Em outro registro, o escritor Mozart Soriano Aderaldo (1917-1995), com base em reportagens de época, descreve a feição do logradouro quando ajardinado, em 1902. O autor afirma que "um catavento puxava água para um depósito que abastecia oito tanques destinados a manter viridentes os canteiros floridos situados nas partes em que se dividia o trecho central"30 (Figura 3).

Segundo ambos os relatos, embora stricto sensu destituído de qualquer função decorativa, o cata-vento da Praça do Ferreira era visivelmente importante para manter viçosos e vistosos os canteiros do jardim.

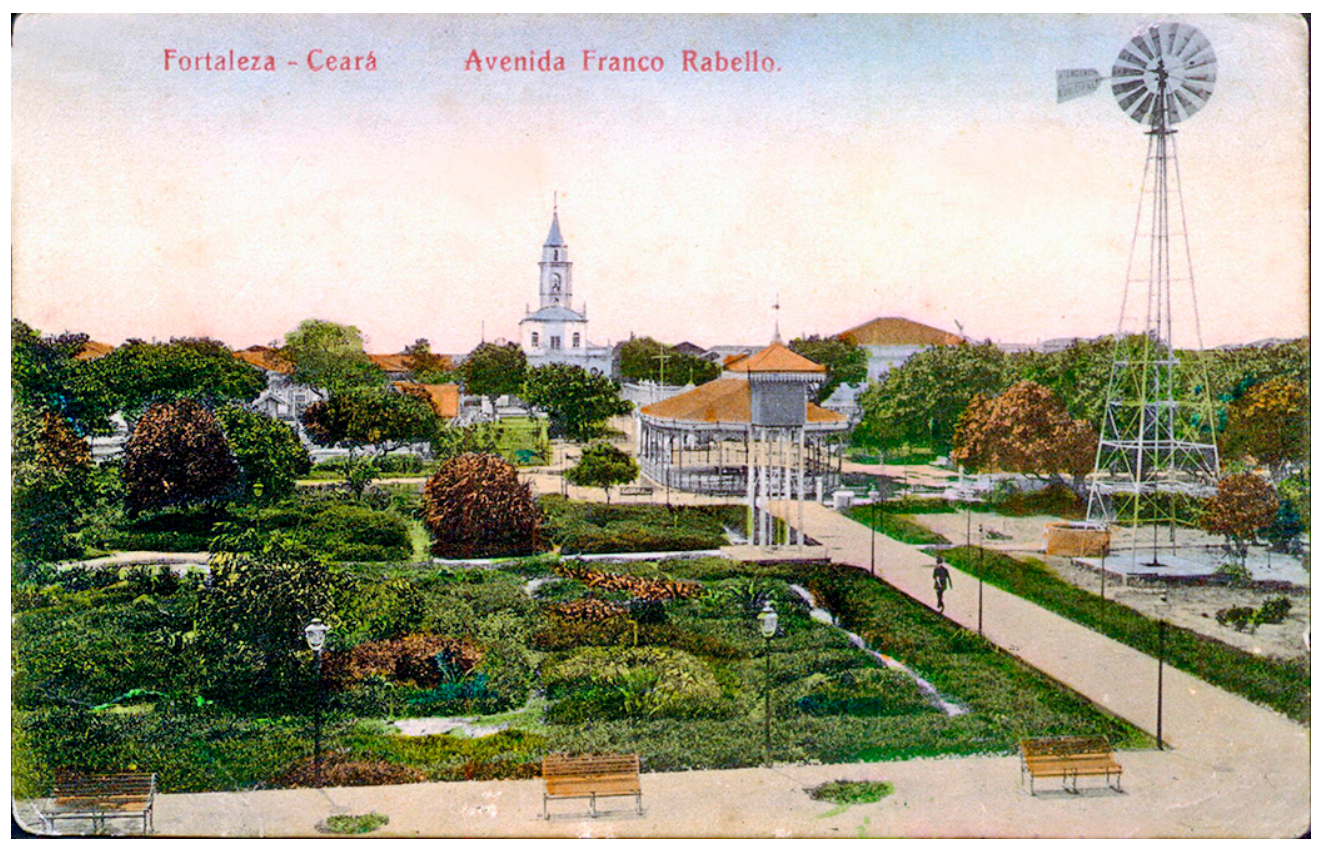

Figura 5 - Jardim Nogueira Accioly da Praça Marquês do Herval (atual Praça José de Alencar), a cacimba, o cata-vento e a caixa-d'água; ao fundo, o pavilhão e a lgreja de Nossa Senhora do Patrocínio, Fortaleza. Cartão postal. Coleção Nirez, Fortaleza.

Enquanto o cata-vento da Praça do Ferreira comparece nas lembranças e escritos de Otacílio de Azevedo e Mozart Soriano Aderaldo, o arquiteto José Liberal de Castro articula a dificuldade de obtenção d'água doce em Fortaleza à concepção projetual do Passeio Público. A despeito de sua filiação às matrizes paisagísticas europeias, o passeio adaptava-se às condições topográficas e hídricas locais, visto que "minguava a água na Cidade, obtida de cacimbas, com dificuldades, e elevada às caixas de distribuição por meio de bombas movidas a braço ou por cataventos". ${ }^{11}$ Liberal de Castro afirma que "o agenciamento em patamares procedia do aproveitamento da disposição rampada do terreno, sem quaisquer vínculos com os jardins à italiana, estes animados pela fartura hídrica, em canais, lagos, fontes e cascatas". ${ }^{32}$
30. Cf. Mozart Soriano Aderaldo (1989, p. 63).

31. Cf. José Liberal de Castro (2009, p. 94).

32. Cf. ibidem, p. 94 
33. Cf. Raimundo Girão (1959, p. 322; 1979, p. 227).

34. Cf. ibidem, 1959, p. 322; 1979 , p. 227.

35. Cf. José Liberal de Castro $(1992$, p. 68-69)

36. Cf. ibidem, p. 69.

37. Cf. O Povo $(3 / 10 / 1928$, p. 3).

38. Cf. O Povo (2/6/1930, p. 8).
Informações sobre a procedência de tais equipamentos constam na obra do escritor e ex-prefeito (1933-1934) Raimundo Girão (1900-1988). O autor afirma que, no início do século XX, os cata-ventos de Fortaleza, "em geral, eram de fabricação norte-americana, quase todos dos tipos Dandy e IXL", e, em razão do seu crescido número, ofereciam "sugestivo aspecto" à cidade. ${ }^{33}$ Ainda segundo o autor, a população supria-se de água por meio de "cacimbas escavadas nos quintais das casas e elevada por moinhos de vento a rodarem desesperadamente dia e noite", ao passo que a água potável "era distribuída pelas residências em cargas de quatro ancoretas ou canecos, transportados por jumentos". ${ }^{34}$

Reafirmando a informação de Girão, José Liberal de Castro registra que os cata-ventos metálicos, existentes "em número incontável" na cidade, eram utilizados nas moradias antes da instalação da rede de distribuição d'água domiciliar, mas também serviam para a irrigação dos jardins públicos. ${ }^{35} \mathrm{Em}$ suas palavras, "os cata-ventos na quase totalidade exibiam, nas pás, o logotipo da marca Dandy, americana, embora alguns exemplares fossem de fabricação local", produzidos pela Fundição Cearense. ${ }^{36}$

Anúncios de época por nós coligidos, cotejados com a bibliografia especializada sobre cata-ventos americanos, corroboram a procedência de tais equipamentos. Alguns anúncios publicitários publicados no jornal $\bigcirc$ Povo em 1928 e 1930 sugerem a oferta de cata-ventos usados, ao mencionarem sua condição "em reforma" ${ }^{37}$ ou "em perfeito estado". ${ }^{38}$

Um anúncio divulgado pelo mecânico Viana referente a um exemplar dandy evidencia a sua procedência dos Estados Unidos, assim como o fato de ter uma caixa-d'água em madeira de cipreste daquele país e ser mensurado em pés unidade de medida do sistema anglo-saxão (Figura 6). $\bigcirc$ cata-vento anunciado tinha 60 pés de altura, equivalentes a 18 metros ou um edifício de seis pavimentos.

\section{Negocio de occasião}

Quem quizer possuir um fogão de 2 metros por 95 . com 12 boccas e installaçũo d'agua quen. te. assim como um catavento Dandy, de 60 pés de altura com caixa d'agua em madeira de eypreste aniericano, pode se dirigir ao VIANNA, travessa das Trincheiras 30 , que Yará negocio.

Outrosim: o logảo só se presta para hoteis - grandes estabelecimentos de ensino.
Figura 6 - Anúncio de venda de cata-vento americano dandy em Fortaleza. Fonte: $\bigcirc$ Povo, Fortaleza, $4 / 10 / 1929$ 
39. Ver T. Lindsay Baker (1985, p. 168 ; 345-346; 392).

cata-vento ou moinho de vento foi um dos vetores da colonização do Oeste e Meio-Oeste americano, ao proporcionar o bombeamento de água subterrânea, viabilizando o assentamento das populações rurais. Além de suprir as necessidades de fazendeiros e estancieiros, forneceu água para as caldeiras das locomotivas e a bombeou para os telhados das habitações verticalizadas do Leste, bem como compareceu em zonas urbanas e em resorts localizados nas montanhas ou no litoral.

Esse panorama é esmiuçado pelo historiador T. Lindsay Baker, que bem aquilatou esses gigantes eólicos, coletando fotos, anúncios e gravuras, fotografando remanescentes, catalogando fabricantes e identificando modelos. Segundo o autor, o moinho dandy era fabricado pela Challenge Company, de Batavia, Illinois, que o produziu por mais de 30 anos, restando vários exemplares nos Estados Unidos e em outros países. ${ }^{39}$ Esse modelo é típico dos moinhos de aço que apareceram no início da década de 1890.40 $\bigcirc$ pesquisador documenta ainda a existência de um dandy em 1930 em Curaçau, Caribe, onde a pouca profundidade dos aquíferos de água doce tornou possível o uso de moinhos americanos para bombeá-la e abastecer a população. ${ }^{41}$ Essa também era a função essencial dos exemplares que registrou em Campeche, capital do estado homônimo no México, onde "uma verdadeira floresta de moinhos de vento industrializados americanos bombeava água para muitos dos residentes da cidade durante a primeira metade do século XX". ${ }^{42}$

Por sua vez, o I.X.L era manufaturado pela Phelps and Bigelow Wind Mill Company (em madeira, pelo menos já em 1881, ou em aço), firma localizada em Kalamazoo, Michigan. ${ }^{43}$

Moinhos de fabricação estadunidense foram largamente exportados entre as últimas décadas do século XIX e início do XX, via remessa oceânica, e alcançaram o Canadá, a Europa e países da América Latina, a exemplo de Cuba, México, Argentina e Uruguai, além de Índia, Austrália, Nova Zelândia, África do Sul, Tunísia e Madagascar, fosse para abastecimento de comunidades ou de rebanhos, fosse para a exploração agrícola ou de minérios. ${ }^{44}$

Baker faz uma breve menção à sua utilização nas regiões áridas das estepes sul-africanas, onde as chuvas são limitadas, de modo que bombeavam água de poços rasos para reservatórios, visando "dar de beber aos carneiros e ovelhas e irrigar pequenos canteiros de jardins". ${ }^{45}$ Chamados de cata-ventos de "múltiplas pás" ou "multipá", muitos passaram a ser utilizados no Brasil desde o final do século XIX para bombeamento d'água, porém não se sabe em que escala. ${ }^{46}$
40. Ver ibidem, p. 168.

41. Ver T. Lindsay Baker (2012, p. 143).

42. Cf. ibidem, p. 145.

43. Ver T. Lindsay Baker (1985, p. 288; 290; 368; 403).

44. Ver T. Lindsay Baker (1985, p. 101-105; 2012, p. 134-145).

45. O autor utiliza a expressão small garden plots, que entendemos se tratar de pequenas hortas ou canteiros de plantas comestíveis, caracterizando um modo de utilização do cata-vento para irrigação agrícola. Cf. T. Lindsay Baker (1985, p. 104).

46. Cf. Companhia Hidro Elétrica do São Francisco $(1987$, p. $11 ; 18)$. 
47. Ver T. Lindsay Baker (1985, p. 102-104).

48. Ver ibidem, p. 101.

49. Cf. ibidem, p. 101.

50. Cf. Raimundo Girão (1979, p. 104).

51. Ver Unitario (19131914), A Tribuna (1922), $O$ Nordeste (1922), Terra Cearense (1925), Correio do Ceará (1930), O Povo (1930), Album de Fortaleza (1931).

52. Cf. José Liberal de Castro (1992, p. 68).

53. Ver T. Lindsay Baker (2012, p. 120).
Enquanto países industrializados inicialmente importadores criaram firmas nativas, os países latino-americanos firmaram-se como o mais amplo e sólido mercado consumidor de moinhos americanos. ${ }^{47} \bigcirc$ pico das exportações dessa produção deu-se nos anos que antecederam a I Guerra Mundial, viabilizadas por meio de representantes ou até de casas filiais instaladas em outros países. ${ }^{48}$ Para tanto, diversos fabricantes produziam peças publicitárias e manuais em idiomas estrangeiros, especialmente espanhol, e afirmavam possuir tais materiais em francês, alemão e "línguas menos comuns", a exemplo do russo e do sueco. ${ }^{49}$ Contudo, não encontramos menção à existência de anúncios em português, agentes comerciais ou lojas filiais atuando no Brasil.

A aquisição de manufaturas dos Estados Unidos em Fortaleza se dava, possivelmente, via empresas de navegação marítima, como a The Booth Steamship Company Limited, a American Brazil Line e a Lamport \& Holt Limited, ligando-a ao porto de Nova York e, mais tarde, ao da Filadélfia, conforme nos leva a crer a afirmação de Raimundo Girão, bem como informações constantes em álbuns e jornais de época. Segundo o autor, "Liverpool fez-se o mais movimentado centro de trocas da praça de Fortaleza, que só mais tarde se foram estendendo a Hamburgo, ao Havre, a Nova York, Barcelona e Trieste". 50

De fato, anúncios das companhias de navegação marítima e notícias do movimento do porto no século XX publicados em periódicos de 1913 a 1931 Unitario, A Tribuna, O Nordeste, Terra Cearense, Correio do Ceará, O Povo e Album de Fortaleza ${ }^{51}$ - indicam que a cidade passou a ter contato direto com Nova York e Filadélfia, além de praças europeias.

\section{Cata-ventos, cacimbas e caixas-d'água: utilização e desmonte do sistema}

Nos jardins de Fortaleza, os cata-ventos estavam geralmente associados a caixas-d'água metálicas, adquiridas provavelmente de países europeus como parte do rico universo de edificações, instalações, equipamentos e componentes arquiteturais importados em massa por países latino-americanos em processo de urbanização a partir do século XIX. Esses reservatórios d'água "destinavam-se à irrigação dos jardins públicos por gravidade" e "formavam binário com cata-ventos destinados a elevar a água das cacimbas adjacentes". 52

Nos Estados Unidos, embora predominantes no contexto rural, cata-ventos eram instalados em áreas urbanas em várias partes do país, já que governos locais financiavam a escavação de poços e a construção de moinhos para uso público. ${ }^{53}$ Cavalos e mulas usados em meios de transporte anteriores à era do automóvel 
demandavam consumo regular de água, de modo que "próximos aos poços construíam-se cochos de concreto, madeira ou aço com lados de altura apropriada para os animais beberem confortavelmente" .54

Esse sistema foi registrado no país a partir do final do século XIX e desapareceu após a década de 1920, com a era do veículo automotor. ${ }^{55}$ As imagens que o autor T. Lindsay Baker fornece de distritos urbanos dos Estados Unidos - Kansas City, no Kansas, e Ruskin e Farnam, em Nebraska - mostram poços e moinhos semelhantes às cacimbas e cata-ventos de Fortaleza, mas nenhum deles instalado em jardins. Tais ilustrações - entre outras de San Diego, na Califórnia, e Canyon, no Texas - retratam cochos, carroças, vias sem pavimentação e áreas livres cobertas por terra, sem tratamento paisagístico, indicando que os moinhos bombeavam água para os animais ou para a população, mas não para a irrigação de jardins públicos.

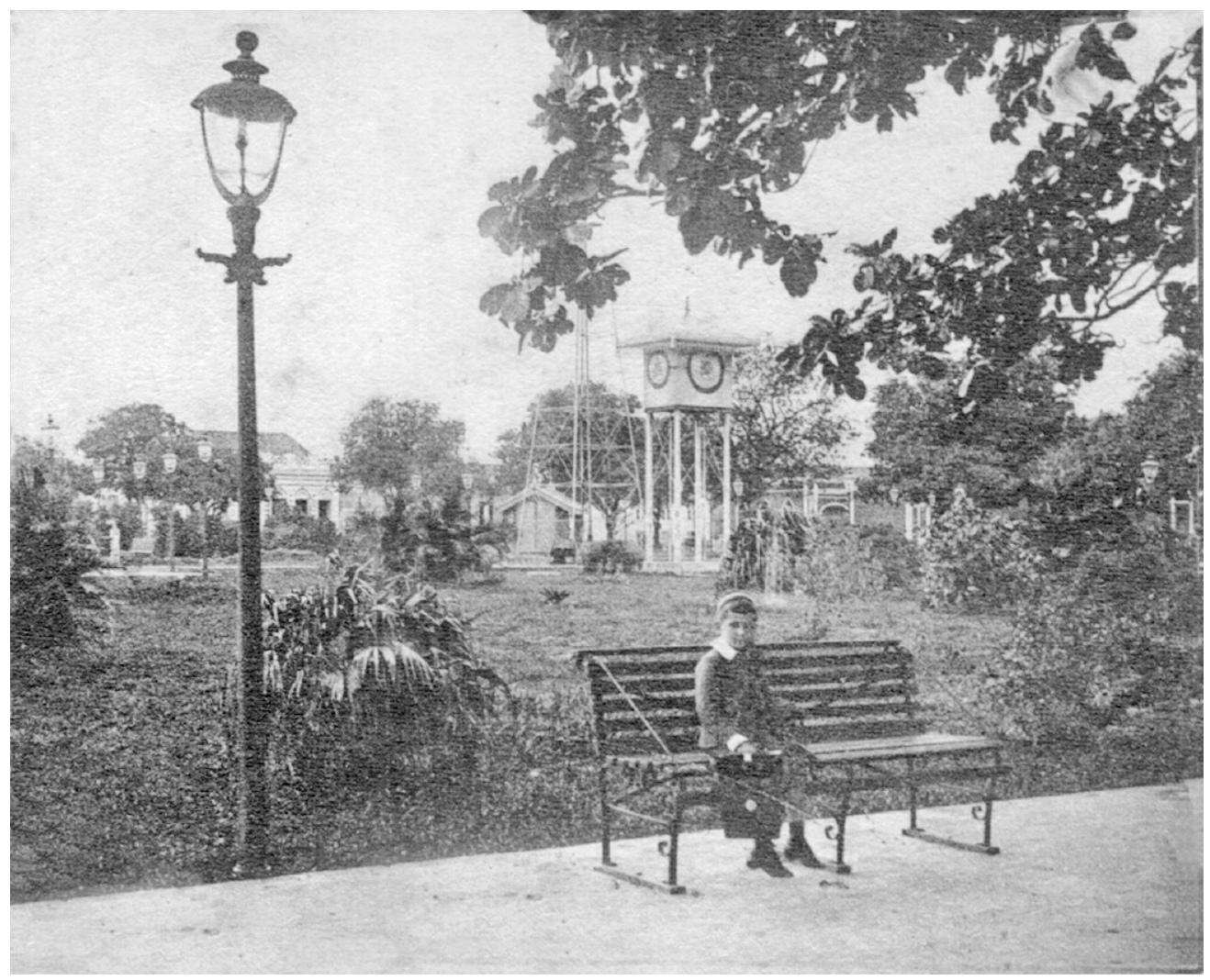

Figura 7 - Jardim Nogueira Accioly da Praça Marquês do Herval (atual Praça José de Alencar), o cata-vento e a caixa d'água, Fortaleza. Coleção Nirez, Fortaleza. Fonte: Fortaleza 1910 (1980).

Em Fortaleza, a exemplo do que ocorria em áreas urbanas dos Estados Unidos, a municipalidade era responsável pela instalação e manutenção de cata- 
56. Cf. Annuario Estatistico do Estado do Ceará, Brasil/ Annuaire Statistique du Ceará, Brésil relativo aos anos de 1922 (1925, p. 425427), 1923 (1926, p. 401-403) e 1924 (1928, p. 394-396).

57. Cf. Raimundo Girão (1979, p. 225).

58. Cf. Gustavo Barroso (1962, p. 283).

59. Cf. Raimundo Girão (1983, p. 68).

60. Cf. Raimundo de Menezes (2006 [1938], p. 47-48).

61. Cf. José Liberal de Castro (2009, p. 108). ventos em logradouros públicos, segundo consta na seção de finanças municipais sob a rubrica "conservação de cataventos e motores" no Annuario Estatistico do Estado do Ceará relativo aos anos de 1922, 1923 e 1924.56

No entanto, no começo do século, ao comentar a seca de 1900, Raimundo Girão afirma que, àquela época, Fortaleza revelava uma "simplicidade provinciana de praças ainda sem jardins, antes monótonos quadros de pastagem do gado à solta" ${ }^{57}$ Naquele tempo, a cidade contava com o Passeio Público, mas ainda não haviam sido ajardinadas as praças do Ferreira e Marquês do Herval, o que veio a ocorrer entre 1902 e 1903.

Sobre a Praça do Ferreira, diz Gustavo Barroso (1888-1959) que, durante a seca de 1877-1879, foi aberta em seu centro uma cacimba em pedra lioz para provisão d'água, ao lado da qual se instalou "um chafariz do sistema que os franceses denominavam fontaine Wallace" ${ }^{58}$ Essa peça parece ter sido substituída posteriormente, já que, na época de seu ajardinamento, em 1902, a praça dispunha de cata-vento e caixa-d'água e bacias para irrigação, conforme anteriormente descrito (Figura 3).

Até então, a Praça do Ferreira era um antigo areal chamado Feira Nova com um "cacimbão no centro", 59 ponto de parada dos comboios vindos do interior, a que se mostrariam úteis "as mongubeiras [Pachira aquatica] e as castanholas [Terminalia catappa] floridas, enchendo o solo da frescura das sombras doces e dos frutos gostosos", ${ }^{\prime} 0$ bem como a água da cacimba, em palavras de Raimundo de Menezes (1903-1984).

É possivel que cacimbas perfuradas para obtenção d'água doce tenham sido aproveitadas quando do ajardinamento de praças, dotadas de cata-ventos e reservatórios. Segundo Liberal de Castro, escavavam-se cacimbas de uso público no ponto central das praças, que, uma vez "ajardinadas, ganhavam caixas-d'água e cataventos, instalações usadas na elevação e na rega dos jardins". ${ }^{61}$

Contudo, segundo a iconografia que coletamos, a Praça General Tibúrcio, ajardinada entre 1913 e 1914, não tinha cata-vento, de modo que desconhecemos quais teriam sido as soluções adotadas para sua irrigação. Por sua vez, a Praça José de Alencar (hoje Waldemar Falcão, que não deve ser confundida com a atual José de Alencar, antiga Marquês do Herval) (Figura 8), embora não ajardinada, era dotada de um cata-vento e de um reservatório, além de um chafariz.

Dessa maneira, supomos que a água bombeada pudesse servir para o consumo dos moradores ou dos animais que trafegavam na cidade anteriormente à popularização do automóvel ou vinham do Sertão - nesse último caso, assemelhando-se ao que ocorria em localidades urbanas dos Estados Unidos. 


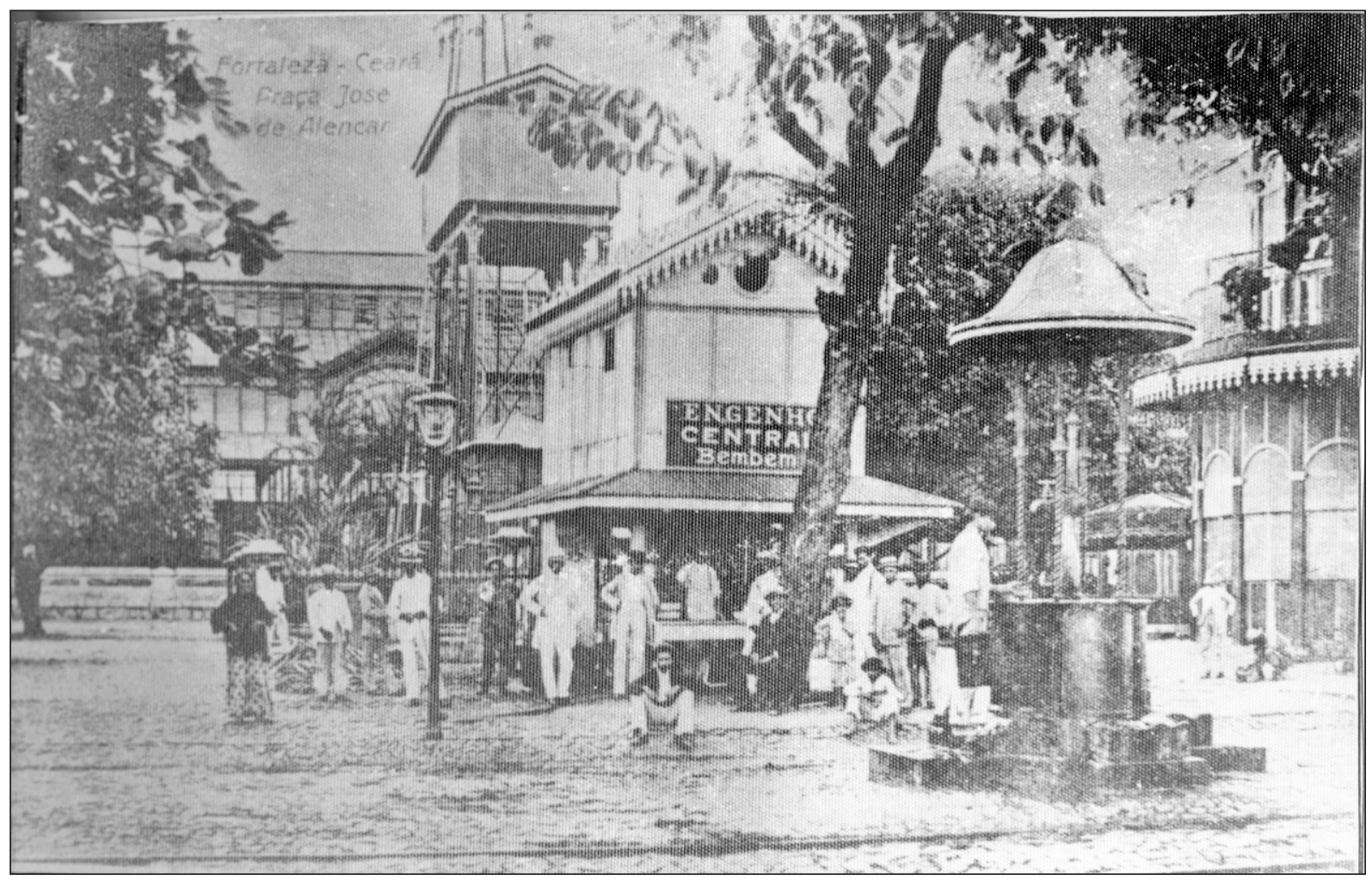

Figura 8 - Praça José de Alencar (atual Praça Waldemar Falcão), o cata-vento, a caixa-d'água e o chafariz, Fortaleza. Acervo do Museu da Imagem e do Som do Ceará, Fortaleza.

A partir dos anos 1930, a iconografia urbana da capital cearense, nela incluindo-se as fotos do Album de Fortaleza, de 1931, mostra que os logradouros urbanos não mais possuíam cata-ventos. Naquela época, a cidade já dispunha do novo serviço de abastecimento d'água, o qual compreendia captação, adução por tubulação, armazenamento em duas caixas-d'água localizadas na Praça Visconde de Pelotas e rede de distribuição (Figura 9).

Esses reservatórios eram remanescentes da década de 1910, pois coube ao governador Antônio Pinto Nogueira Accioly 11896-1900, 19041912) iniciar as obras do sistema de abastecimento d'água, o qual foi inaugurado somente posteriormente, na gestão estadual de José Moreira da Rocha (1924-1928).62 O novo serviço, todavia, tinha "capacidade de abastecimento parcial à população".63

Fotos daquela época indicam que, se por um lado os cata-ventos já haviam desaparecido das praças ajardinadas, sua existência resistia nos quintais das casas, pois ainda deviam desempenhar importante papel no fornecimento d'água para 0 consumo doméstico. Segundo Emy Falcão Maia Neto, em 1927, os cata-ventos

\begin{abstract}
62. Ver José Liberal de Castro (1987, p. 231-232; 250); Raimundo Girão (1979, p. 230); Sebastião Rogério Ponte (1999, p. 16).
\end{abstract}

63. Cf. Sebastião Rogério Ponte (1999, p. 82). 
64. Cf. Emy Falcão Maia Neto $(2015$, p. 207-208).

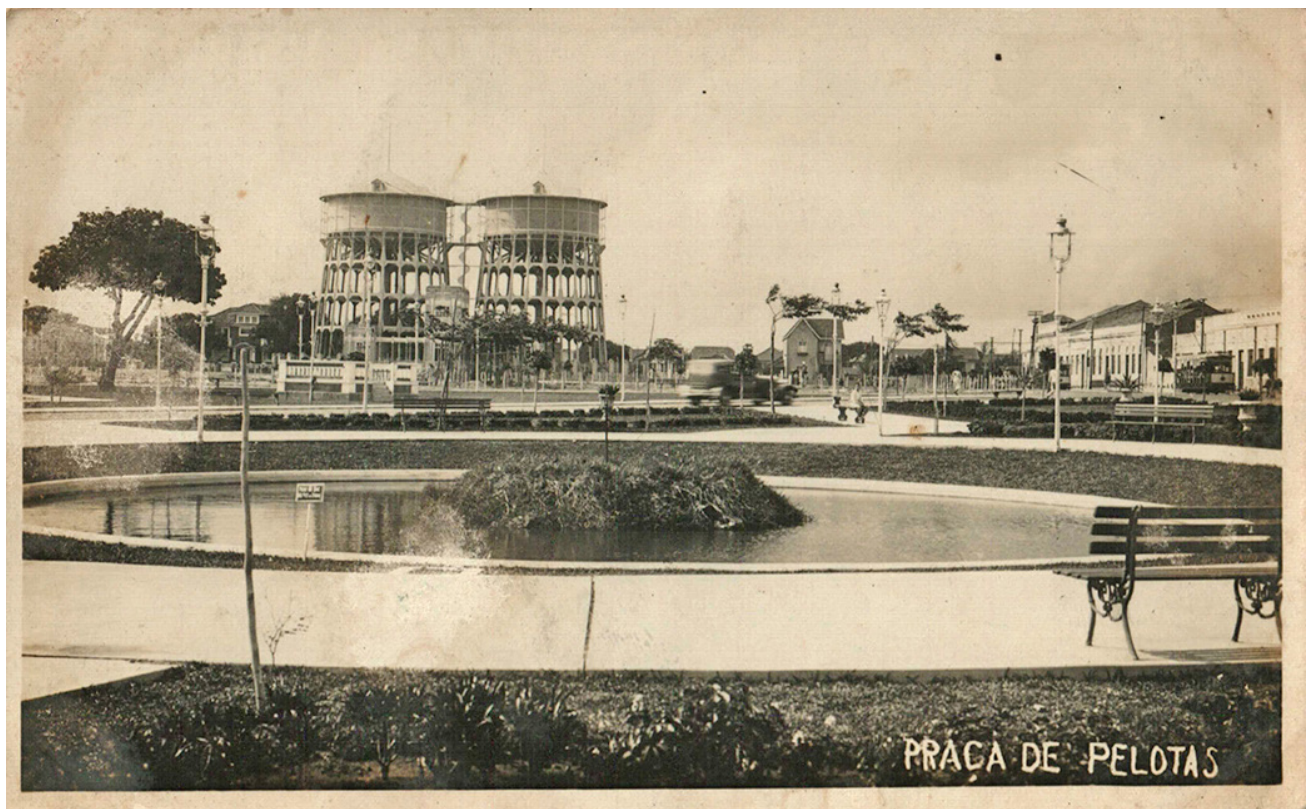

Figura 9 - Praça Visconde de Pelotas (ałual Praça Clóvis Beviláqua) e as duas caixas-d'água, Fortaleza. Cartão postal. Coleção da autora, Salvador.

continuavam sendo anunciados pelas funilarias, sinalizando que faziam "circular água aonde a rede ainda não chegava ou como uma fonte alternativa para fugir dos preços cobrados". 64

Naquela década, após a reforma completa que the foi imputada, em 1925, no governo do prefeito Godofredo Maciel (1924-1928), a Praça do Ferreira, que antes possuía cata-vento e caixa-d'água (Figura 3), aparece destituída de ambos em fotos da época (Figura 10). Tais imagens ainda deixam ver a presença de fícus-benjamim (Ficus benjamina) no contorno da praça, exemplificando o plantio de espécies arbóreas resistentes, conforme apontamos anteriormente.

O desaparecimento do sistema de irrigação por moinho eólico também se verifica na Praça José de Alencar. Em 1929, em seu espaço central, antes ocupado por pavilhão, cata-vento e reservatório d'água (Figuras 5 e 7), foi instalada a escultura do escritor que nomeia o logradouro (Figura 11 ).

Portanto, admitimos que os anúncios veiculados pelo jornal $O$ Povo entre 1928 e 1930 e antes referidos ofereciam, de fato, cata-ventos usados, tendo particulares como possíveis interessados. Esse é um marco cronológico razoável para o seu desaparecimento dos jardins públicos da cidade, ainda que permanecessem nas propriedades privadas. 


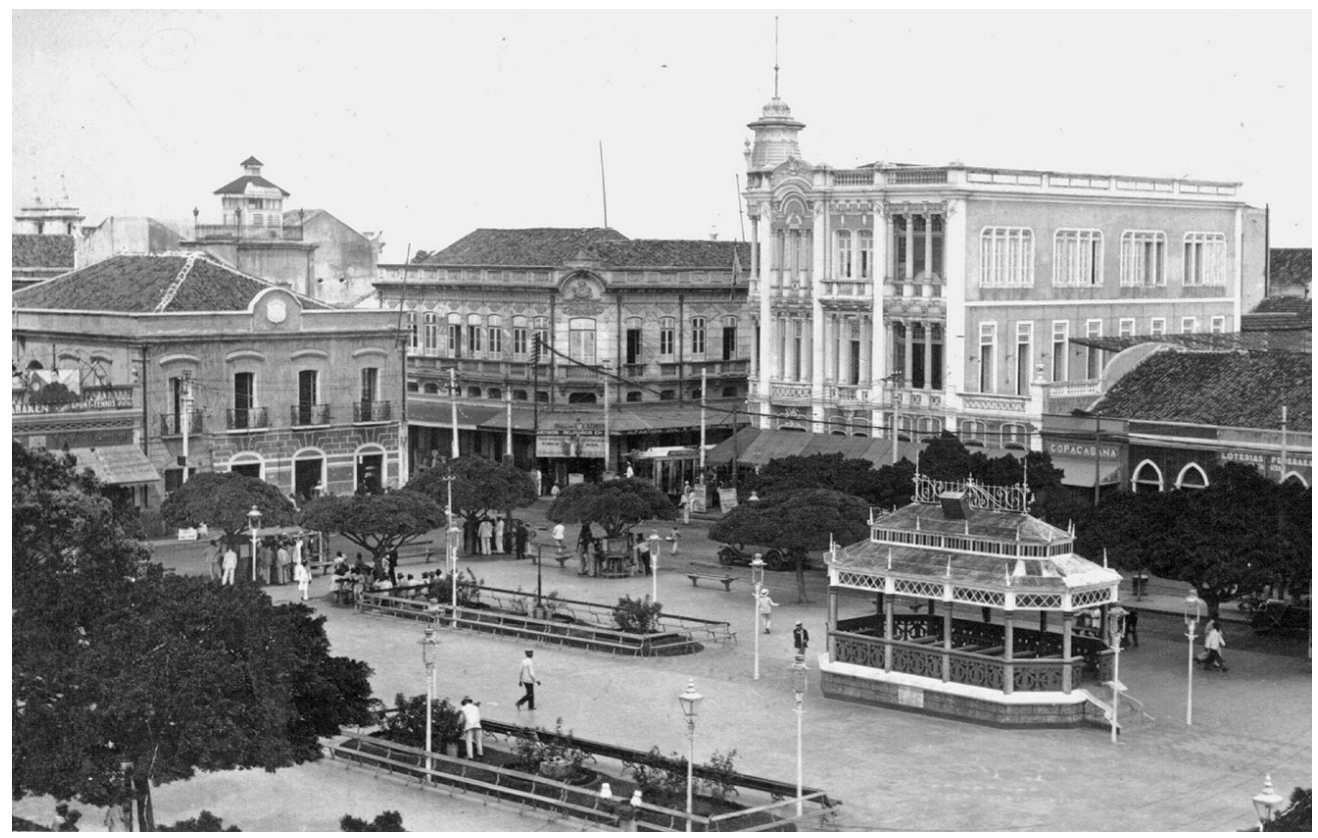

Figura 10 - Praça do Ferreira (antes Jardim 7 de Setembro da Praça do Ferreira) após a remodelação de 1925, podendo-se notar o coreto e a ausência do sistema cata-vento/cacimba/caixa-d'água, Fortaleza. Coleção Nirez, Fortaleza.

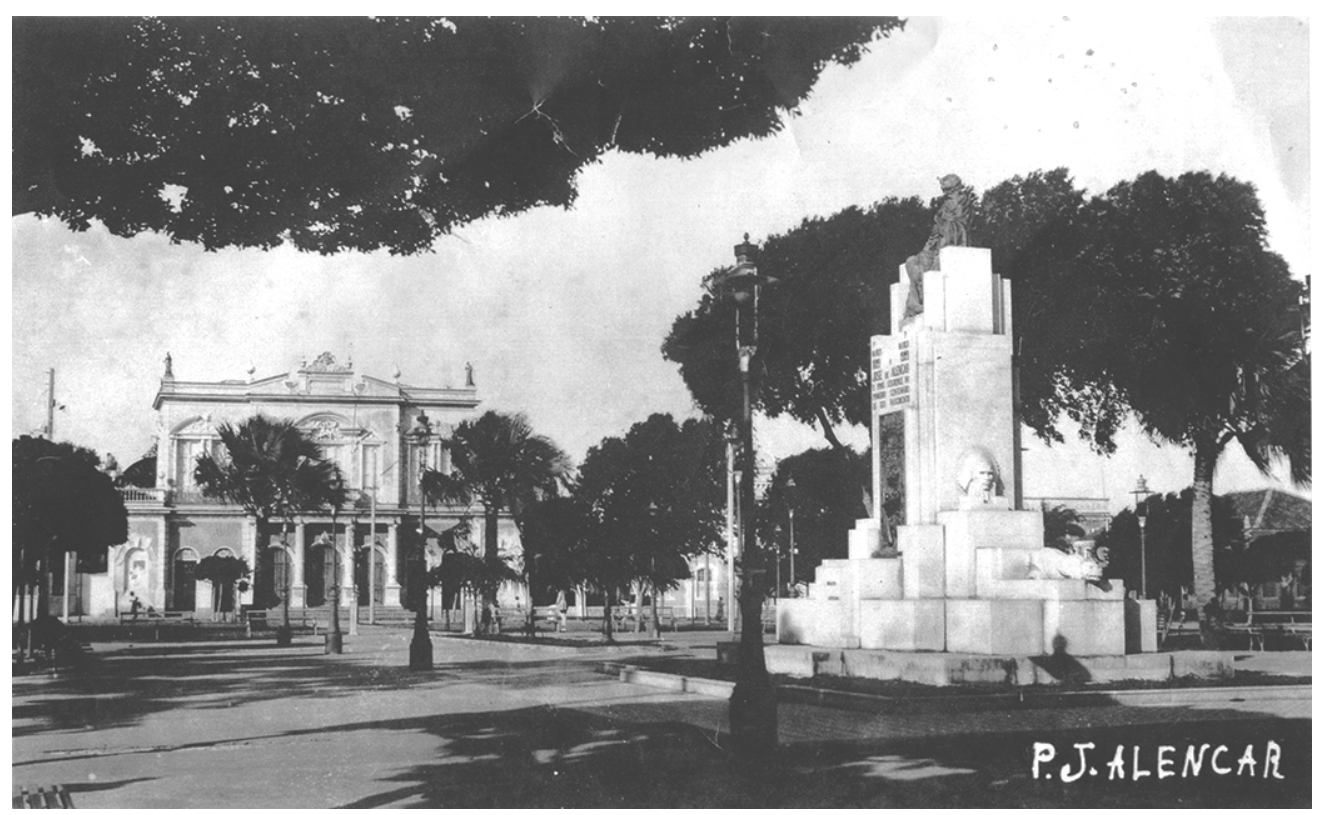

Figura 11 - Praça José de Alencar (antes Jardim Nogueira Accioly da Praça Marquês do Herval) e a estátua do escritor José de Alencar (inaugurada em 1\%/5/1929). Ausência do sistema cata-vento/ cacimba/caixa-d'água. Fonte: Acervo Museu da Imagem e do Som do Ceará, Fortaleza 
65. Cf. Fernando Atique (2010, p. 25).

\section{CONCLUSÕES}

A partir das reflexões aqui reunidas, buscamos evidenciar os atributos do meio como fatores essenciais no cultivo dos jardins públicos de Fortaleza, ao elegermos elementos vegetais, recantos contemplativos e artefatos utilitários árvores, lagos, cata-ventos e reservatórios - que permitam problematizar as representações sobre o Brasil relacionadas à exuberância da natureza tropical e à abundância de recursos naturais.

Nos jardins fortalezenses, a seleção de espécies arbóreas, a escassez de peças aquáticas e a instalação de cata-ventos nos conduzem a refletir sobre as releituras das referências paisagísticas europeias mediadas pelo contexto fisiográfico, associado a fatores de ordem cultural. Assim, delineamos novas interpretações acerca dos jardins públicos do Oitocentos e início do Novecentos que ultrapassem a especificidade do caso examinado.

A instalação de moinhos eólicos nos jardins de Fortaleza, recorrentes nos rincões rurais dos Estados Unidos, despontava como uma evidente solução de adaptação à geografia local, proporcionando água para a irrigação das plantas e o possível consumo da população e dos animais e fincando marcas na paisagem urbana.

Por outro lado, admiráveis no porte e na frequência com que foram retratados em fotos e cartões-postais, os cata-ventos de Fortaleza são desconhecidos da literatura sobre o paisagismo no Brasil. Sua expressiva presença na Cidade dos Verdes Mares the valeria o epíteto de Cidade dos Cata-ventos.

Nesse sentido, segundo Fernando Atique, se a vinculação com os arranhacéus de Nova York, símbolo da costa leste americana, ainda é pouco tratada pela historiografia da arquitetura e do urbanismo no Brasil, o relacionamento do país "com as formas e imagens da costa oeste" dos Estados Unidos permanece um "tabu", 65 ao qual acrescentamos a região do Meio-Oeste, em razão dos conceitos e significados corporificados nos moinhos eólicos.

Desse modo, esperamos que, ao reunir evidências empíricas da ligação do Brasil com a cultura material americana, o presente relato possa espraiar algumas fontes e referências até então pouco utilizadas nos estudos históricos sobre os jardins brasileiros. 


\section{REFERÊNCIAS}

FONTES PRIMÁRIAS

A TRIBUNA. Fortaleza, 1\%/7/1922 a 30/9/1922.

ALBUM DE FORTALEZA. Fortaleza: organizado por Paulo Bezerra, autor e proprietário, 1931. Disponível em: <www.ceara.pro.br/Raridades/Album_Fortaleza_1931.html>. Acesso em: 7 maio 2014.

ANNUARIO Estatistico do Estado do Ceará, Brasil/Annuaire Statistique du Ceará, Brésil, 1922 - VII Anno/Année, Fortaleza: Typ. Moderna, 1925.

ANNUARIO Estatistico do Estado do Ceará, Brasil/Annuaire Statistique du Ceará, Brésil, 1923 - VIII Anno/Année, Fortaleza: Typ. Moderna, 1926.

ANNUARIO Estatistico do Estado do Ceará, Brasil/Annuaire Statistique du Ceará, Brésil, 1924 - IX Anno/Année, Fortaleza: Typ. Moderna, 1928.

ARBORIZAÇÃo da cidade: Appello ás mães de família. Correio do Ceará, Fortaleza, 31/7/1930, p. 7.

AVISO em geral. O Povo, Fortaleza, 3/10/1928, p. 3.

CEARÁ ILLUSTRADO, Fortaleza, anno I, n. 28, 18 de janeiro de 1925. Disponível em: <www. secult.ce.gov.br/index.php/equipamentosculturais/biblioteca-publica/ceara-ilustrado?start=40>. Acesso em: 28 julho 2013.

CORREIO DO CEARÁ. Fortaleza, 2/5/1925 a 30/5/1925; 24/12/1929 a 31/12/1929; 1\%/7/1930 a 30/8/1930; 8/9/1930 e 27/9/1930.

FORTALEZA 1910. Fortaleza: Imprensa Universitária da Universidade Federal do Ceará, 1980. (Edição fac-similar do Album de Vistas do Ceará 1908, editado por iniciativa da firma Boris Frères).

IMPRESSÕES de Fortaleza. Correio do Ceará, Fortaleza, 16/8/1930, p. 7. 
O NORDESTE. Fortaleza, 29/6/1922 a 30/12/1922. In: ALVES, Marinez; FIGUEIRÊDO, Madalena. (Org.). Catálogo da Hemeroteca do Instituto do Ceará (Histórico, Geográfico e Antropológico). Fortaleza: Instituto do Ceará, 2010.

O POVO. Fortaleza, 7/1/1928 a 30/12/1933.

CATAVENTO. O Povo, Fortaleza, 2/6/1930, p. 8.

NEGOCIO de occasião. O Povo, Fortaleza, 4/10/1929, p. 4.

TERRA CEARENSE. Album de Propaganda em geral, organizado no governo do eminente desembargador José Moreira Maciel da Rocha. Edição Português-Italiano. Fortaleza, 1925. Disponível em: <www.ceara.pro.br/Raridades/Terra_Cearense_1925.html>. Acesso em: 7 maio 2014.

UNITARIO. Fortaleza, 12/9/1903 a 30/6/1904; 24/1/1913 a 30/4/1913; 1\%/1/1914 a 31/12/1914.

LIVROS, ARTIGOS, DISSERTAÇÕES E TESES

ADERALDO, Mozart Soriano. A Praça. Fortaleza: Gráfica Editora R. Esteves Tiprogresso Ltda, 1989.

ANDRADE, Rubens. Antonio Lemos e as obras de melhoramentos urbanos em Belém: a Praça da República como estudo de caso. Dissertação (Mestrado em Arquitetura) - UFRJ, Rio de Janeiro, 2003.

ATIQUE, Fernando. Arquitetando a "boa vizinhança": arquitetura, cidade e cultura nas relações Brasil-Estados Unidos, 1876-1945. Campinas: Pontes; Fapesp, 2010.

AZEVEDO, Otacílio de. Fortaleza descalça. 3. ed. Fortaleza: Secult-CE, 2012.

BAHLS, Aparecida Vaz da Silva. O verde na metrópole: a evolução das praças e jardins em Curitiba (1885-1916). Dissertação (Mestrado em História) - UFPR, Curitiba, 1998.

BAKER, T. Lindsay. A Field Guide to American Windmills. Norman, Oklahoma: University of Oklahoma Press, 1985. 
American Windmills: an Album of Historic Photographs. Norman, Oklahoma:

University of Oklahoma Press, 2012.

BANCO DO NORDESTE DO BRASIL. Do passado ao futuro. Fortaleza: BNB, 1984.

BARROSO, Gustavo. À margem da bistória do Ceará. Fortaleza: Imprensa Universitária, 1962.

BARTALINI, Vladimir. Parques públicos municipais de São Paulo: a ação da municipalidade no provimento de áreas verdes de recreação. Tese (Doutorado em Arquitetura e Urbanismo) - USP, São Paulo, 1999.

BELLINI, Anna Karine de Queiroz Costa. Espaços públicos abertos e o usufruto da paisagem: 1860 a 1912 - Vitória (ES). Dissertação (Mestrado em Arquitetura e Urbanismo) - UFES, Vitória, 2014.

BEZERRA, Ricardo Figueiredo; ROCHA, Fernanda Cláudia Lacerda; SÁ CARNEIRO, Ana Rita; OLIVEIRA, Temístocles Anastácio de. Roberto Burle Marx e o Theatro José de Alencar: um projeto em dois tempos. Fortaleza: Laboratório de Estudos em Arquitetura e Urbanismo, UFC; Laboratório da Paisagem, Unifor, 2012.

CASTRO, José Liberal de. Arquitetura do ferro no Ceará. Revista do Instituto do Ceará, Fortaleza, ano CVI, p. 63-94, 1992.

. Arquitetura Eclética no Ceará. In: FABRIS, Annateresa (Org.). Ecletismo na arquitetura brasileira. São Paulo: Nobel; Edusp, 1987. p. 209-255.

Passeio Público: espaços, estatuária e lazer. Revista do Instituto do Ceará, Fortaleza, ano 123, p. 41-114, 2009. Disponível em: <www.ceara.pro.br/Instituto-site/Rev-apresentacao/ RevPorAnoHTML/2009indice.html>. Acesso em: 5 agosto 2011.

COMPANHIA HIDRO ELÉTRICA DO SÃO FRANCISCO. Fontes energéticas brasileiras: Inventário/Tecnologia. Rio de Janeiro: Brascep Engenharia Ltda, 1987. (Volume 1 - De cataventos a aerogeradores, o uso do vento).

DOURADO, Guilherme Mazza. Belle Époque dos jardins. São Paulo: Editora Senac, 2011.

FOLLY, Luiz Fernando Dutra. A bistória da Praça Princesa Izabel em Nova Friburgo: o projeto esquecido de Glaziou. Dissertação (Urbanismo) - UFRJ, Rio de Janeiro, 2007.

FREITAS, Cândida. O Parque 13 de Maio na modernização do Recife. Dissertação (Mestrado em Desenvolvimento Urbano) - UFPE, Recife, 2006. 
GIRÃO, Raimundo. Fortaleza e a crônica histórica. Fortaleza: Imprensa Universitária da UFC, 1983.

Geografia Estética de Fortaleza. 2. ed. Fortaleza: BNB, 1979.

Geografia Estética de Fortaleza. Fortaleza: Imprensa Universitária do Ceará, 1959.

HETZEL, Bia; NEGREIROS, Silvia (Org.). Glaziou e as raízes do paisagismo no Brasil. Rio de Janeiro: Manati, 2011.

HOUAISS, Antônio. Dicionário Houaiss eletrônico da língua portuguesa. Versão 3.0. Rio de Janeiro: Editora Objetiva, 2009. CD-ROM.

KLIASS, Rosa Grena. Parques urbanos de São Paulo e sua evolução na cidade. São Paulo: Pini, 1993.

LIMA, Siomara Barbosa Stroppa de. Para além da arquitetura: Ramos de Azevedo e os projetos de jardins para Campinas. In: SÁ CARNEIRO, Ana Rita; PÉREZ BERTRUY, Ramona (Org.). Jardins bistóricos brasileiros e mexicanos. Recife: Editora da UFPE, 2009. p. 141-173.

LUZ, Luis Fernando da. Parque Farroupilha: composição e caráter de um jardim público de Porto Alegre. Dissertação (Mestrado em Arquitetura) - UFRGS, Porto Alegre, 1999.

MACEDO, Silvio Soares. Quadro do paisagismo no Brasil. São Paulo: O Autor, 1999.

MAGALHÃES, Cristiane Maria. Medicina entre flores na belle époque do sul mineiro: os jardins paisagísticos nas cidades das águas. In: SAES, Alexandre Macchione; MARTINS, Marcos Lobato (Org.). Sul de Minas em transição: a formação do capitalismo na passagem para o século 20. Bauru, SP: Edusc, 2012. p. 265-301.

MAIA NETO, Emy Falcão. Cartografias da água: territorialidades, políticas e usos da água doce em Fortaleza (1856-1926). Tese (Doutorado em História) - UFC, Fortaleza, 2015.

MENEZES, Raimundo de. Coisas que o tempo levou: crônicas históricas da Fortaleza antiga. Fortaleza: Edições Demócrito Rocha, 2006.

MESQUITA, Liana de Barros. Memória dos verdes urbanos do Recife. Cadernos do Meio Ambiente do Recife, Recife, v. 1, n. 1, p. 11-58, abr.-jun. 1998. 
NOBRE, Paulo José Lisboa; PEREIRA, Marizo Vitor; RIBEIRO, Isaías da Silva. Un estudio sobre jardines históricos: manifestaciones del paisaje cultural en la ciudad de Natal/RN, Brasil. Apuntes, Bogotá, n. 1, v. 22, p. 54-67, 2009. Disponível em: <http://revistas. javeriana.edu.co/sitio/apuntes/sccs/plantilla_detalle.php?id_articulo=226>. Acesso em: 20 fevereiro 2014.

NOGUEIRA, João. Cidade da Fortaleza - Nomes atuais e antigos de suas praças (em itálico as denominações não oficiais). Nomes antigos de alguns trechos da cidade. Paióis da Pólvora. Chafarizes. Frades de Pedra, Arborização. Usos antigos. Revista do Instituto do Ceará, Fortaleza, ano LVI, p. 147-152, 1942.

Fortaleza velha. Fortaleza: Instituto do Ceará, 1954.

PARADEDA, Maria Regina Matos. Arquitetura da paisagem e modernidade: um estudo sobre representações e memória das praças de Pelotas (1860-1930). Dissertação (Mestrado em História) - PUC-RS, Porto Alegre, 2003.

PONTE, Sebastião Rogério. Fortaleza Belle Époque: reformas urbanas e controle social - 18601930. 2. ed. Fortaleza: Fundação Demócrito Rocha, 1999.

SÁ CARNEIRO, Ana Rita. Parque e paisagem: um olhar sobre o Recife. Recife: Ed. Universitária da UFPE, 2010.

; PÉREZ BERTRUY, Ramona (Org.). Jardins históricos brasileiros e mexicanos. Recife: Editora Universitária da UFPE, 2009.

SEGAWA, Hugo. Ao amor do público: jardins no Brasil. São Paulo: Studio Nobel; Fapesp, 1996.

SILVA, Aline de Figueirôa. Entre a implantação e a aclimatação: o cultivo de jardins públicos no Brasil nos séculos XIX e XX. Tese (Doutorado em Arquitetura e Urbanismo) - USP, São Paulo, 2016.

Jardins do Recife: uma história do paisagismo no Brasil (1872-1937). Recife: Cepe, 2010.

; SILVA, Joelmir Marques da. Entre a formosura e o refrigério: a vegetação nos jardins do Recife nos anos 1920. In: ENOKIBARA, Marta; GHIRARDELLO, Nilson; SALCEDO, Rosio Fernández Baca (Org.). Patrimônio, paisagem e cidade. Tupã, SP: Associação Amigos da Natureza da Alta Paulista (Anap), 2016. p. 83-99. 
TERRA, Carlos Gonçalves. O jardim no Brasil no século XIX: Glaziou revisitado. 2. ed. Rio de Janeiro: EBA-UFRJ, 2000.

. Paisagens construídas: jardins, praças e parques do Rio de Janeiro na segunda metade do século XIX. Rio de Janeiro: Rio Books, 2013.

Artigo apresentado em 08/10/2016. Aprovado em 30/04/2017.

\section{(cc) BY}

